\title{
Free Exercise on the Mountaintop
}

\author{
James D. Gordon III†
}

In this dialogue on a mountaintop, a student and his spiritual teacher explore the contours of the free exercise clause of the first amendment. The Supreme Court dramatically narrowed that clause in Employment Division v. Smith, which concerned the religious use of peyote by Native Americans. The teacher and the student examine aspects of the decision, including the importance of the unemployment compensation context of the case and the fate of the "compelling governmental interest" test. The teacher concludes by the end of the discussion that the Smith Court mistreated precedent, used shoddy reasoning, and, except in the unemployment compensation area, deprived the free exercise clause of any independent significance.

On a remote mountaintop, a student (S) approaches his spiritual teacher (T).

S: Hello, my friend.

T: Peace.

S: I bring news from civilization ${ }^{1}$ about the freedom of rehgion.

T: Good. When I was a law professor, ${ }^{2}$ I wrote a book about the free exercise clause of the first amendment.

S: A book would hardly be necessary now; a pamphlet would suffice. The United States Supreme Court drastically narrowed the free exercise clause in Employment Division v. Smith. ${ }^{3}$

T: What were the facts of the case? ${ }^{4}$

$\dagger$ Professor of Law, Brigham Young University. B.A. 1977, Brigham Young University; J.D. 1980, University of California, Berkeley. I didn't do very well in constitutional law. That semester my final grades were four F's and a D. The Dean called me into his office and said, "Kid, you've got to stop spending all your time on one subject." Apologies and thanks to Dave Barry, Steve Benson, Juanita Brooks, Johnny Carson, Jesse H. Choper, W. Cole Durham, Jr., Ralph Waldo Emerson, Frederick Mark Gedicks, Bruce C. Hafen, Duane E. Hiatt, Edward L. Kimball, Henry Kissinger, Jay Leno, Michael W. McConnell, Rita Rudner, Barry G. Silberman, Steven D. Smith, Mark V. Tushnet, Lynn D. Wardle, Kevin J. Worthen, and others.

1. When Mahatma Gandhi was asked what he thought of Western civilization, he replied, "I think it would be a good idea." R. ByrNe, The Other 637 Best Things ANyBody EVER SAID No. 620 (1984).

2. This spiritual leader was a law professor before he repented. His area of concentration has shifted from wordmongering to ineffability. Law professors generally make ineffective ininisters. Carl Sandburg said, "I won't take my religion from any man who never works except with his mouth." G. LIEBERMAN, 3,500 GOOD QUOTES FOR SPEAKERS 202 (1983).

3. 110 S. Ct. 1595 (1990).

4. Despite repentance, old patterns die hard. 
S: A private drug rehabilitation organization fired two members of the Native American Church because they ingested peyote for sacramental purposes. Oregon criminal law prohibited the possession of peyote. Oregon demied them unemployment compensation under a state law disqualifying employees discharged for work-related "misconduct." The church members sued, alleging that the demals violated their rights under the free exercise clause of the first amendment. ${ }^{5}$

T: The basic legal framework in this area has been established for nearly thirty years. Under the Sherbert ${ }^{6}$ test, the free exercise clause requires an exemption from a law burdening the free, exercise of rehgion unless the law is necessary to the accomphishment of an important ("coinpelling") governmental interest and is the least restrictive means of achieving that interest. ${ }^{7}$ I presume that the Court held that the Oregon statute coinbatimg drug abuse satisfied this test?

S: No. The Court rejected the test completely. ${ }^{8}$ It held that the free exercise clause provides no protection agamst a generally applicable criminal law $w^{9}$ regulating conduct.

T: Then what does the free exercise clause protect?

S: The Court held that it excludes governmental regulation of religious behiefs. ${ }^{10}$

T: But the "exercise" of rehgion includes more than mere behefs: ${ }^{11}$

5. Smith, $110 \mathrm{~S}$. Ct. at $1597-98$. Illegal aliens have always been a problem in this country. Ask any Native American. See Robert Orben, in R. BYRNE, supra note 1, at No. 523.

6. Sherbert v. Verner, 374 U.S. 398 (1963).

7. Hernandez v. Commissioner, 109 S. Ct. 2136, 2148 (1989); Frazee v. Illinois Dep't of Employment Sec., 109 S. Ct. 1514, 1518 (1989); Hobbie v. Unemployment Appeals Comm'n, 480 U.S. 136, 141 (1987); Thomas v. Review Bd., 450 U.S. 707, 718 (1981); Sherbert, 374 U.S. at 403. See generally McConnell, The Origins and Historical Understanding of Free Exercise of Religion, 103 HARV. L. REV. 1409, 1416-20 (1990) (describing modern free exercise doctrine and arguing that the survival of the principle of free exercise exemptions is threatened). For a critique of prevailing judicial definitions of the required burden on free exercise, see Lupu, Where Rights Begin: The Problem of Burdens on the Free Exercise of Religion, 102 HARV. L. REV. 933 (1989).

8. The plaintiffs may have lost because their counsel pronounced Justice Scalia's naine improperly. Justice Scalia has written:

I think it's generally agreed among all the justices of the Supreme Court that the most unadmirable characteristic of appellate counsel is mispronouncing the word "SCA-LEEAH." Better you should say simply, "Justice," or "Mr. Justice," or "Sir," or even "Madain," than that you should say "Justice 'Scalya." " Several regretably [sic] important cases have been lost because of that just this term.

Proceedings of the Forty-Ninth Judicial Conference of the District of Columbia, 124 F.R.D. 241, 28485 (1988).

9. Smith, $110 \mathrm{~S}$. Ct. at $1602-06$. Therefore, there is usually no free exercise proteetion against a criminal conviction. "Conviction, n. (1) If you're a crook, the law's way of telling you to slow down." Morris, The New (Legal) Devil's Dictionary, 6 J. ConTEMP. L. 231, 232 (1979).

10. Smith, $110 \mathrm{~S}$. Ct. at 1599. Big deal. In totalitarian regimes, you can also believe whatever you want. After all, how can the government stop you?

11. For exaunple, some churches believe in ten commandments. Others are more lax-they have six commandments and four "do-the-best-you-cans." Cf. Satehel Paige's Six Rules for Life:

Avoid fried foods which angry up the blood. If your stomach disputes you, pacify it with 
it includes conduct-certain acts or abstentions. ${ }^{12}$

S: The Court acknowledged that fact. ${ }^{13}$ With respect to conduct, the Court held that the free exercise clause prohibits a law banning certain acts or abstentions only when they are engaged in for rehgious reasons, or only because of the religious belief ${ }^{14}$ that they display. ${ }^{15}$ For example, the Court said that it would be illegal "to ban the casting of 'statues that are to be used for worship purposes,' or to prohibit bowing down before a golden calf."16 Similarly, it would be illegal to prohibit people from praying in private. ${ }^{17}$ In other words, a law prohibits the free exercise of religion only if it is "speeifically directed"18 at a religious practice.

T: What historical evidence pertaining to the free exercise clause did the Court refer to?

S: None. ${ }^{19}$

T: Not a single reference ${ }^{20}$

S: Perhaps no evidence exists, so inquiry would be futile.

T: On the contrary, historical evidence does exist. For example, a

cool thoughts. Keep the juices flowing by jangling around gently as you move. Go very lightly on the vices, such as carrying on in society, as the social ramble ain't restful.' Avoid runming at all times. Don't look back, something might be gaining on you.

P. Dickson, The Official Rules 141 (1978).

12. See Marcus, The Forum of the Conscience: Applying Standards Under the Free Exercise Clause, 1973 DukE L.J. 1217, 1234; McConnell, supra note 7, at 1451-52, 1488-90 (discussing historical evidence from the period of the founding); Pepper, The Conundrum of the Free Exercise Clause-Some Reflections on Recent Cases, 9 N. KY. L. REV. 265, 265 (1982).

13. Smith, $110 \mathrm{~S}$. Ct. at 1596. Indeed, the framers rejected the terminology "rights of conscience" and adopted instead "free exercise of religion," suggesting an intent to protect religiously motivated conduct as well as belief. McConnell, supra note 7, at 1481-84, 1488-90.

14. Rehigious beliefs vary widely. For example, some people believe that lawyers existed before the creation of the world. They point to the condition that existed before creation and ask, "Who do you think created all that chaos?"

15. Some people are cynical about religions belief. Hear, e.g., LED ZEPPELIN, Stainway to Heaven (sound recording on 4th, untitled album) (Atlantic Records 1971). However, the band has simply adopted another philosophy-Epicureanism-as its rehigion. Former demigod Jimmy Page looks like he celebrates the wonders of about 50 roast beef sandwiches a day.

16. Smith, 110 S. Ct. at 1599 (citing two rcalistic exanples).

17. Cf. Daniel 6:7-9 (King Darius' decree that any person who prayed to anyone other than the king would be cast into a den of lious). Law professor and California Law Review Editor-inChief-Emeritus Michael Tigar is said to be such a flerce advocate that, when he appears before the Court, he is like a lion in a den of Daniels.

18. Smith, $110 \mathrm{~S}$. Ct. at 1599.

19. It did, however, cite some hysterical evidence, which I will discuss later. See infra text aecompanying notes $87-88$. Smith's lack of historical inquiry is by no means exceptional. Although cases interpreting the establishment clause have often focused on historical content and meaning, no Supreme Court opinion-majority, concurring, or dissenting-has ever based its interpretation of the free exercise clause on historical meaning. McConnell, supra note 7, at 1413.

20. This is somewhat surprising, given that Jnstice Scalia, the opinion's author, is one of the foremost advocates of the view that the Constitution should be interpreted in light of its original meaning. See Scalia, Originalism: The Lesser Evil, 57 U. CIN. L. REv. 849 (1989). 
historical study concluded that at the time of ratification, constitutionally compelled exemptions were within the framers' contemplation as a possible imterpretation of the free exercise clause, and that exemptions were consonant with the popular American understanding of the interrelation between the claims of a limited government and a sovereign God. ${ }^{21}$

S: Perhaps it is not surprising that the Court declined to refer to historical evidence.

$\mathrm{T}$ : In any event, the Court must have overruled the many cases settimg forth the compelling interest test.

S: Not at all; it distinguished them. For example, some of the cases involved unemployment compensation rules that conditioned the availability of benefits on an applicant's willingness to work under conditions forbidden by his rehigion, and did not involve a generally applicable criminal law. The Court held that the compelling imterest test applies ouly to the former cases. ${ }^{22}$

T: This distimction would undoubtedly have eluded the drafters, since unemployment compensation was unknown in 1789. What difference does it make whether a practice is a violation of criminal law or a ground for denying unemployment compensation?

S: The Court said that the distmction was "critical, for "if Oregon does prohibit the rehgious use of peyote, and if that prohibition is consistent with the Federal Constitution, there is no federal right to engage in that conduct in Oregon,' and 'the State is free to withhold unemployment compensation.' "23

$\mathrm{T}$ : It is tautological that there is no constitutional right to engage in conduct that a state can constitutionally prohibit. ${ }^{24}$ Moreover, a

21. McConnell, supra note 7, at 1415. Assuming that the test is to apply the principles underlying the free exercise clause rather than its historical meaning, that test might create a greater role for the free exercise clause today than it had at the time of ratification:

The Religion Clauses were adopted in 1789 as limitations on an already-limited government. The sphere of federal government action was narrow; conflicts between religion and the federal government, as originally envisioned, would be few. The growth of the modern welfare-regulatory state has vastly increased the occasions for conflict between government and religion. The government has entered areas formerly private and often religious, .... and has enacted regulations affeeting religious institutions, such as labor and antidiscrimination laws. To maintain the vitality and independence of religious life as it was in 1789 requires, even more clearly than it did at that time, a recognition of the special character and needs of religion.

McConnell, Accommodation of Religion, 1985 SUP. CT. REv. 1, 23-24.

22. Smith, $110 \mathrm{~S}$. Ct. at 1600 . This distinction rests on the proposition that no difference is so small that it can't be blown out of proportion.

23. Id. at 1598-99 (quoting Employment Div. v. Smith, 485 U.S. 660, 672 (1988)).

24. The Court's circular argument is not an example of straight thinking. Straight thinking is generally preferred, based on the assumption that we live in a Euclidean universe. $C f$. Village of Euclid v. Ambler Realty Co., 272 U.S. 365 (1926) (implicitly assuming that every point on the surfaee of a sphere is unique). But cf. Tribe, The Curvature of Constitutional Space: What Lawyers Can Learn From Modern Physics, 103 HARV. L. REv. 1 (1989). 
state's failure to criminalize certain conduct does not create a federal right to engage in that conduct.

I don't understand why the government ${ }^{25}$ can imprison people for practicing their religion but cannot deny them unemployment benefits. ${ }^{26}$ The free exercise clause permits lieavy burdens ${ }^{27}$ on religion but not light ones? ${ }^{28}$

S: In fact, when this case came before the Court previously, the Court held that "if a State las prohibited through its criminal laws certam kinds of religiously motivated conduct without violating the First Amendment, it certainly follows that it may impose the lesser burden of denying unemployinent compensation benefits to persons who engage im that conduct." 29 Therefore, the uneinployinent coinpensation exemption may ultimately come to be perceived as simply historical. While the exemption may be illogical, in the law, as Justice Holmes observed, "a page of history is wortll a volume of logic."30

T: However, the free exercise clause presently protects people against the denial of unemployment coinpensation for religious practices. But wait-didn't this case involve a denial of unemployment compensation?

S: Yes, but the denial came about because of a general criminal law.

T: So? The state imposed the same burden on a religious practice and mcurred the same cost to its compensation fund.

S: The Oregon Supreme Court agreed. It lield that the criminality of respondents' peyote use was irrelevant since the purpose of the "misconduct" clause was not to enforce the state's criminal laws but to

25. Pronounced "govment." Exec. Order No. 12345 (signed by Jimmy Carter and extended by Ronald Reagan).

26. Perhaps the Court has been influenced by the law and economics movement's axiom that freedom, justice, and human dignity are nothing compared to the ultimate value-wealth.

27. The violation of a man's religion or conscience often works an exceptional harm to him which, unless justifled by the most stringent social needs, constitutes a moral wrong in and of itself, far more than would the impairment of his freedoms of speech, press or assembly. The argnment is not merely that avoiding compulsion of a man's conscience produces the greatest good for the greatest number, but that such compulsion is itself unfair to the individual concerned. The moral condemnation implicit in the threat of criminal sanctions is likely to be very painful to one motivated by belief. Furthermore, the cost to a principled individual of failing to do his moral duty is generally severe, in terms of supernatural sanction or the loss of moral self-respect. In the face of these costs, the individual's refusal to obey the law may be mevitable, and therefore in some perhaps unusual sense of the word, involuntary.

Clark, Guidelines for the Free Exercise Clause, 83 HARv. L. REv. 327, 337 (1969).

28. Perhaps the Justices had personally sampled some of the exhibits in the record.

29. Employment Div. v. Smith, 485 U.S. 660, 670 (1988).

30. New York Trust Co. v. Eisner, 256 U.S. 345, 349 (1921). 
preserve the financial integrity of the compensation fund. ${ }^{31}$ The United States Supreme Court held that its past unemployment compensation cases simply meant that if a state permits individual exemptions from unemployment compensation regulations, it may not refuse to extend that system to cases of rehigious hardship. ${ }^{32}$ The Court explained that the compelling interest test had developed in "a context that lent itself to individualized governmental assessinent of the reasons for the relevant conduct."33

$\mathrm{T}$ : Where did that distimction come from?

S: The Smith Court said that a "plurality of the Court" had noted the distimction in Bowen v. Roy. ${ }^{34}$ But that was a mischaracterization: in Bowen, only three Justices concurred in that part of the opinion, while five Justices rejected the distinction. ${ }^{35}$

T: The Oregon unemployment compensation system requires a determination of whether the employees engaged in "misconduct." Isn't that a "context that [lends] itself to imdividualized governmental assessment of the reasons for the relevant conduct'?

S: Yes. Under the apphicable Oregon regulation, the definition of "misconduct" invites consideration of the reasons for the conduct. ${ }^{36}$ But

31. Smith v. Employment Div., 301 Or. 209, 219, 721 P.2d 445, 450 (1986), vacated, 485 U.S. 660 (1988).

32. Employment Div. v. Smith, 110 S. Ct. 1595, 1604 (1990).

33. Id. at 1603 . The Court explained that

a distinctive feature of unemployment compensation programs is that their cligibility criteria invite consideration of the particular circumstances behind an applicant's unemployment: "The statutory conditions [im Sherbert and Thomas] provided that a person was not eligible for unemployment compensation benefits if, 'without good cause,' he had quit work or refused available work. The 'good cause' standard created a mechanism for individualized exemptions."

Id. (quoting Bowen v. Roy, 476 U.S. 693, 708 (1986)).

34. Id.

35. Bowen, 476 U.S. at 715-16 (Blackmun, J., concurring); id. at 726-32 (O'Connor, J., joined by Brennan, J., and Marshall, J., concurring in part and dissenting in part); id. at 733 (White, J., dissenting). The Smith Court admitted that three Justices joined in the so-called "plurality," Smith, 110 S. Ct. at 1603 , but failed to point out that five Justices disagreed. On the other hand, perhaps the Court's statement was not a mischaracterization at all, and instead rested on the following mathematical formula: $x^{2}+4 x y+3>x^{2}+2 x y+5$. The two variables arc unknowable and therefore may be assumed not to exist. Replacing the variables with zeros reveals that $3>5$. In its dealings with Congress over the years, the Court has proved many times that $9>535$. In any event, the Smith Court's 5-1-3 decision demonstrates the supremacy of the irrational numbers over the transcendental numbers.

36. Under the provisions of ORS 657.176(2)(a) and (b), misconduct is a wilful violation of the standards of behavior which an employer has the right to expect of an employee. An act that amounts to a wilful disregard of an employer's interest, or recurring negligence which demonstrates wrongful intent is misconduct. Isolated instances of poor judgment, good faith errors, unavoidable accidents, absences due to illness or other physical or mental disabilities, or mere inefficiency resulting from lack of job skills or experiencc are not misconduct for purposes of denying benefits under ORS 657.176 .

OR. ADMIN. R. 471-30-038(3) (1979), quoted in Smith v. Employment Div., 301 Or. 209, 215, 721 P.2d 445, 448 (1986), vacated, 485 U.S. 660 (1988). 
the Court ignored that fact.

T: According to Smith, the free exercise clause protects conduct only in an uneinployment coinpensation system and only if that system examines apphicants' individual reasons for their unemployed condition. These distinctions hardly seem defensible. ${ }^{37}$

S: They permit the Court to carefully avoid ${ }^{38}$ overturning recent precedent. If Smith had been decided before those cases, the Court probably would not have carved this area out for separate treatinent.

T: Hadn't the Court apphed the coinpelling interest test in contexts other than unemployment compensation?

S: Everyone thought so, including the Court. However, Justice Scalia, writing for the majority, stated that the Court had only "purported" to apply the coinpelling interest test in those contexts, ${ }^{39}$ but had "always" found the test satisfied. ${ }^{40}$

T: The fact that the Court found the test satisfied does not inean that it apphed no test at all.

S: Nevertheless, the Court asserted, "We have never held that an individual's rehgious beliefs ${ }^{41}$ excuse hiln froin comphance with an otherwise valid law prohibiting conduct that the State is free to regulate." ${ }^{42}$

T: That statement is almost Orwellian; it is a manifestly false statement of history. ${ }^{43}$ In Wisconsin $v$. Yoder, ${ }^{44}$ the Court invalidated compulsory school-attendance laws as apphed to Amish parents who refused on rehigious grounds to send their children to public schools. In Cantwell v. Connecticut, ${ }^{45}$ the Court invalidated a licensing system for religious and charitable solicitations as apphed to the claimants. In Follett $v$. McCormick ${ }^{46}$ and Murdock v. Pennsylvania, ${ }^{47}$ the Court invalidated a flat tax on solicitation as applied to the dissemination of religious ideas.

S: The Court distinguished those cases as involving "not the Free

37. When cows laugh, does milk come out of their noses?

38. This should have been caught by the Law Review's Split Infinitive Editor.

39. Smith, $110 \mathrm{~S}$. Ct. at 1600 . The implication is that the Court had either been dishonest in those cases or was being so in Smith.

40. For the Court, "always" seems to mean "in two cases." Id. (citing United States v. Lee, 455 U.S. 252 (1982) (social security taxes), and Gillette v. United States, 401 U.S. 437 (1971) (compulsory nilitary service)). If there were only one case, the Court would have said "In our experience ....." If there were three cases, it would have said, "Time after time after time . . .."

41. "I have an existential nap. It has 'You are here' written all over it." Steven Wright, in $R$. BYRNE, supra note 1 , at No. 324.

42. Smith, $110 \mathrm{~S}$. Ct. at 1600 .

43. Mark Twain said, "Most writers regard the truth as their most valuable possession, and therefore are most economical in its use." R. BYRNE, supra note 1, at No. 354.

44. 406 U.S. 205 (1972).

45. 310 U.S. 296 (1940).

46. 321 U.S. 573 (1944).

47. 319 U.S. 105 (1943). 
Exercise Clause alone, but the Free Exercise Clause in conjunction with other constitutional protection, such as freedom of speech and of the press."

T: Did those decisions actually rest on other constitutional grounds, and was the discussion of the free exercise clause in those cases simply dictum? Or does the Court mean that the free exercise clause has meaning only when it is combined with another constitutional right?

S: Presuinably the former. A constitutional right that has meanmg only when it is combined with another right ${ }^{49}$ would be anomalous.

$T$ : The Court's reasoning is overly ingenious. The fact that a decision rests on two alternative grounds does not mean that one ground is dictum. Otherwise, decisions resting on more than one ground would have no precedential value at all, snice no one could tell which was the real ground and which was dictuin.

Moreover, in each of those cases the Court exphicitly rested its decision on the free exercise clause. ${ }^{50}$ For exaniple, in Yoder the Court expressly stated that it granted certiorari to review the free exercise claim, ${ }^{51}$ and its opimion discussed that legal issue most. ${ }^{52}$

S: Nevertheless, Justice Scalia pointed out that Yoder also involved the right of parents to direct the religious education of their children, ${ }^{53}$ a right imphed in the Constitution. ${ }^{54}$

T: Because the decision addressed both an express right and an

48. Smith, $110 \mathrm{~S}$. Ct. at 1601 (citations omitted). In addition, the Court pointed out that Wooley v. Maynard, 430 U.S. 705 (1977), which was decided solely on free speech grounds, also involved the freedom of religion. In that case, the Court held that a person did not have to use an automobile license plate bearing New Hampshire's state slogan, "Live Free or Die." Id. at 717. A few years ago, Wisconsm ("The Dairy State") held a contest for a new state slogan. One suggestion was "Eat Cheese or Die." However, some people interpreted it as a threat, and it was rejected.

One Idaho resident filed a class action seeking \$23 million in damages from the state for being foreed to advertise Idaho's "Famous Potatoes" on his license plate. The exeeutive director of the Idaho Potato Commission responded that Idaho potatoes are better recognized than almost any other state's produce. He observed, "You say "Florida" and people will say a lot of different things .. . [b]ut if you say "Idaho," they'll always say "potato." ' " Wall St. J., Mar. 11, 1987, § 2, at 39, col. 1 (eastern ed.).

49. Cf. Hamburger Helper.

50. See Cantwell v. Connecticut, 310 U.S. 296, 303-07 (1940) (invalidating statute requiring certification for solicitation of funds for a religious cause); Follett, 321 U.S. at 576-78; Murdock, 319 U.S. at 108, 114. The attempt to distinguish these cases might prove unconvincing. "Some opinions, like some judges, are never distingnished." Morris, supra note 9, at 233.

51. Wisconsin v. Yoder, 406 U.S. 205, 207 (1972).

52. Id. at 209 n. $4,213-29,234$.

53. Smith, 110 S. Ct. at $1601 \&$ n.1 (citing Yoder, 406 U.S. at 233).

54. Pierce v. Society of Sisters, 268 U.S. 510, 534-35 (1925) (compulsory public school attendance uncoustitutional interference with parental right to direet children's education). I believe that parents should have considerable latitude in raising their children. However, I am disturbed that parents tend to be strict with their older children and lax with their younger ones. I was the oldest child, and my parents made me do chores twelve hours a day. By the time the youngest child came along, the only rule was "No herom in the living room." I do admit, though, that being a 
imphed right, the Court in Smith presumed that the case rested solely on the imphied right, and that the express right meant nothing. ${ }^{55}$ This logic came from Justice Scalia, the archenemy of imphied rights. ${ }^{56}$

Moreover, if Cantwell rested solely on free speech, why did it bother to incorporate ${ }^{57}$ the free exercise clause into the fourteenth amendment (as part of tle "fundamental concept of liberty") and apply it to the states? ${ }^{58}$ The Smith Court was simply engaging in clumsy revisiomism.

S: The majority opimon also argued that in recent years the Court lad declined to apply the compelling interest test outside the unemployment compensation field at all. ${ }^{59}$ The opimion cited Goldman $v$. Weinberger, ${ }^{60}$ O'Lone v. Estate of Shabazz, ${ }^{61}$ Bowen v. Roy, ${ }^{62}$ and Lyng v. Northwest Indian Cemetery Protective Association. ${ }^{63}$

T: Goldman and $O^{\prime} L o n e$ involved military and prison regulations, respectively. In those cases, the Court explained that because of the special disciplimary issues mvolved, it traditionally lias given greater deference to such regulations than to regulations affecting civilians. ${ }^{64}$

Bowen and Lyng imvolved the internal affairs doctrine. Bowen lield thiat the government can use tlie social security number of a claimant who believes she will be spiritually imjured by sucli use. Lyng held that

parent eventually wears people down. Martin Mull said that having children is like having a bowling alley installed in your brain. R. BYRNe, supra note 1, at No. 125.

55. Even columnist George F. Will, who lauded Justice Scalia's opinion, admitted that the attempt to distinguisl Yoder was unconvincing. Will, Religion Is Secondary to Democracy, Deseret News, Apr. 20, 1990, at 6A.

56. Cf. Webster v. Reproductive Health Servs., 109 S. Ct. 3040, $3064-67$ (1989) (Scalia, J., concurring) (reiterating his desire to reconsider and overrule the holding of Roe v. Wade, 410 U.S. 113 (1973), that woinen have a constitutional riglit to an abortion). In interpreting the Bill of Rights, Justice Scalia apparently prefers subtraction to addition.

57. "Incorporation, $n$. In constitutional law, magic, sleight-of-hand, whereby the nine-man prestidigitator clooses a number between 1 and 10 and clianges it into a 14 ..." Morris, supra note 9 , at 233.

58. Cantwell v. Connecticut, 310 U.S. 296, 303 (1940) ("The fundamental concept of liberty embodied in [the Fourteenth] Amendinent embraces the liberties guaranteed by the First Amendinent. The First Amendment declares that Congress shall make no law respecting an establisliment of religion or prolibiting the free exercise thereof.") (footnote omitted).

59. See Smith, $110 \mathrm{~S}$. Ct. at 1602.

60. 475 U.S. 503 (1986) (uplolding Air Force regulation that forbids the wearing of unauthorized lieadgear indoors as applied to Orthodox rabbi wearing a yarmulke).

61. 482 U.S. 342 (1987) (upholding prison regulations that had the effect of preventing Mushin inmates froin attending religious services).

62. 476 U.S. 693 (1986) (holding that requiring a social security number for receipt of governmental benefits does not violate the free exercise of Native American religion).

63. 485 U.S. 439 (1988) (holding that frce exercise clause does not prolibit government froin allowing timber harvesting or building a road on land sacred to Native Americans).

64. Goldman, 475 U.S. at 507-08; O'Lone, 482 U.S. at 349; Smith, 110 S. Ct. at 1612 (O'Connor, J., concurring) (Goldman and O'Lone arose in "narrow, specialized contexts" in which coinpelling state interest is not required).

"Inalienable Rights, n. pl. Those rights which the Army takes froin you during basic training and gives back to you one by one as privileges." Morris, supra note 9, at 233. 
the government can build a road and conduct logging operations on its own land despite objections based on Native American religious beliefs. In both cases, the Court distinguished Sherbert on the ground that the first amendinent does not "require the Government itself to behave in ways that the individual beheves will further his or her spiritual development ... . The Free Exercise Clause simply cannot be understood to require the Government to conduct its own internal affairs in ways that comport with the rehigious behefs of particular citizens." 65

The majority in Smith was wrong: The Court had not abandoned the compelling interest test in its recent cases. In fact, the Court applied the compelling interest test in 1989 in Hernandez v. Commissioner. ${ }^{66}$ But perhaps the Court simply overlooked that case.

S: Overlooked but didn't forget. The Court itself cited Hernandez for the compelling interest test. ${ }^{67}$

T: The Court had to distinguish a huge number of cases to reach its holding in Smith. ${ }^{68}$ What is the logic underlying the Court's decision? ${ }^{69}$

S: Perhaps the Court worried that a proliferation of free exercise exemptions could interfere with the operation of the crininal law. ${ }^{70}$ Consequently, it returned to the 1878 holding of Reynolds $v$. United

65. Bowen, 476 U.S. at 699; see Lyng, 485 U.S. at 440 (quoting Bowen); Smith, 110 S. Ct. at 1611-12 (O'Connor, J., concurring) (quoting Sherbert v. Verner, 374 U.S. 398, 412 (1963) (Douglas, J., concurring) ("This distinction inakes sense because "the Free Exercise Clause is written in terms of what the government cannot do to the individual, not in terms of what the individual can exact from the government." ")).

66. 109 S. Ct. 2136, 2148 (1989) (limits on tax deductions for charitable payment to church not in violation of free exercise clause).

67. Smith, $110 \mathrm{~S}$. Ct. at 1602 . Fortunately, Supreine Court Justices are not under oath. However, Americans are generally too critical of the Supreme Court. At least half the lies they tell about it are not true. See G. BRANDRETH, THE JoY of LEX 227 (1980) (quoting Boyle Roche).

68. Professor Michael McConnell said that Smith is "one of the clearest reversals of important constitutional precedent in a decade." Wash. Post, Apr. 18, 1990, at A5, col. 4 (final ed.). The dissenters in Smith wrote that the case "effectuates a wholesale overturning of settled law." Smith, 110 S. Ct. at 1616 (Blackmun, J., dissenting).

69. This question assumes there is an underlying logic. The opinion could be like professional wrestling: artificial feats of strength and a predetermined outcome.

70. On the political spectrum, some of the Justices are slightly to the right of RoboCop. They have never seen a crininal statute they didn't like, or a minority religion they did.

Agreeing with Smith, coluımist George F. Will wrote, "A central purpose of America's political arrangenents is the subordination of religion to the political order . . . . The founders ... wished to tame ... religious passions .... They aimed to do so not by establishing religion but by establishing a connnercial republic-capitalisin." Will, supra note 55. Will did not explain how he knows that the founders intended to replace religion with the free narket. Will's logic, however, speaks for itself: "Hence Americans would not "establish' religion. Rather, by guaranteeing free exercise of religions, they would inake religions private and subordinate." Id. If you understand this, please write ine. 
States ${ }^{71}$ that the free exercise clause protects beliefs ${ }^{72}$ but not conduct. ${ }^{73}$ The Court reasoned that recognizing exemptions except where tlie state shows a compelling interest would permit an individual to "becoine a law unto himself." 74

T: That language imphies that the claimant almost automatically prevails. But the compelling interest test does not work that way. An exemption is not self-executing, arising simply upon its assertion. The test permits courts to balance tlie burden on the individual's first amendment rights against the government's interest in enforcing a particular law. It creates an exeinption only when courts resolve the balance in favor of the individual. ${ }^{75}$ Free exercise exemptions do not inake each person a "law unto himself":

An arm of the government, the court, decides in each instance what the reach of the law will be. The Free Exercise Clause draws a boundary between the powers of the government and the freedoin of the individual, but that boundary is defined and enforced by the government. The significance of the Free Exercise Clause is that the defimition and enforcement of the boundary is entrusted to the arm of the government inost likely to perform the function dispassionately and best equipped to consider the speeifics of the case. The individual behever is not judge in his own case. ${ }^{76}$

In fact, the Court's opinion contains a fundamental inconsistency. ${ }^{77}$

71. 98 U.S. 145 (1878) (upholding anti-polygamy law as applied to Mormons). The Court's return to Reynolds set the clock back 100 years. Several of the current Justices have been praised as having some of the finest nineteenth-century minds in America.

72. The ancient Egyptians worshipped cats. Why anyone would consider cats worthy of worship is frankly beyond me. According to Garrison Keillor, "Cats are intended to teach us that not everything in nature has a function." $R$. BYRNE, supra note 1, at No. 439.

73. Reynolds, 98 U.S. at $166-67$, cited in Smith, 110 S. Ct. at 1600 . A not wliolly dissimilar example of the belief-conduct distinction is Oliver Cromwell's directive regarding religious hberty to the Catholics in Ireland: "As to freedoin of conscience, I ineddle witl no man's conscience; but if you mean by that, liberty to celebrate the Mass, I would have you understand that in no place where the power of the Parliament of England prevails shall that be permitted." S. Hook, ThE Paradoxes of Freedom 23 (1962), quoted in McDaniel v. Paty, 435 U.S. 618, 631 n.2 (1978) (Brennan, J., concurring).

74. Smith, $110 \mathrm{~S}$. Ct. at 1603 (quoting Reynolds, 98 U.S. at 167).

75. A thoroughgoing balancing test would ineasure threc elements of the competing governinental interest: first, the importance of the secular value underlying the governmental regulation; second, the degree of proximity and necessity that the chosen regulatory means bears to the underlying value; and third, the impact that an exemption for religious reasons would have on the over-all regulatory program. This assessinent of the state's interest would then have to be balanced against the claim for religious liberty, which would require calculation of two factors: first, the sincerity and importance of the religious practice for which special protection is clained; and second, the degree to which the governmental regulation interferes with that practice.

' Giannella, Religious Liberty, Nonestablishment, and Doctrinal Development, 80 HARV. L. REv. 1381, 1390 (1967).

76. McConnell, Free Exercise Revisionism and the Smith Decision, 57 U. CHI. L. REv. 1109, 1150 (1991).

77. Then again, a foolish consistency is the hobgoblin of sinall minds. 
In discussing the cases (not involving employment compensation) that used the compelling interest test, the Court argued that in those cases the claimants had "always" lost. ${ }^{78}$ But the Court's principal reason for rejecting the compelling interest test was that, under the test, claimants almost always wim. The Court cannot have it both ways. ${ }^{79}$

The truth is that sometimes the government wins and sometimes the claimant wins. For example, it could be argued that in Smith the state's interest in coinbating drug abuse satisfied the compelling interest test.

S: That's what Justice O'Connor argued in her concurrence. ${ }^{80}$ Justices Blackmun, Brennan, and Marshall disagreed, ${ }^{81}$ arguing that recognizing an exeinption would not undermine the governunent's interest in drug traffickmg, since there is practically no illegal traffic in peyote. ${ }^{82}$

The Court rejected the compellimg interest test, though, argumg that "[a]ny society adopting such a systein would be courting anarchy."

T: The coinpelling interest test has been the law since $1963 .{ }^{84}$ Has it led to anarchy?

S: No. ${ }^{85}$ But the Court cited a parade of horribles, ${ }^{86}$ asserting that the rule

would open the prospect of constitutionally required religious exemptions from civic obhigations of almost every conceivable kind-ranging from compulsory military service, to the payment of taxes, to health and safety regulations such as manslaughter and child neglect laws, compulsory vaccination laws, drug laws, and traffic laws; to social welfare legislation such as minimum wage laws, child labor laws, animial cruelty laws, environmental protection laws, and laws providing for equality of oppor-

78. Smith, 110 S. Ct. at 1602 (citing United States v. Lee, 455 U.S. 252 (1982) (upholding imposition of social secnrity taxes as to employer who claimed that payment of the taxes and receipt of benefits violated his rehigious beliefs) and Gillette v. United States, 401 U.S. 437 (1971) (upholding law refusing to exempt from military service those with religious objection to "unjust wars")).

79. On the other hand, perhaps it can. This may be one of the mysteries.

80. See Smith, $110 \mathrm{~S}$. Ct. at 1613-15 (O'Connor, J., concnrring). Justice O'Connor concluded that "granting a selective exemption in this case would seriously impair Oregon's compelling interest im prohibiting possession of peyote by its citizens." Id. at 1614 .

81. See id. at 1617-23 (Blackmun, J., dissenting).

82. Id. at 1620 (Blackmun, J., dissenting). Justice Blackmun concluded that "Oregon's interest in enforcing its drug laws against religious use of peyote is not sufficiently compelling to outweigh respondents' right to the free exercise of their religion." Id. at 1622. rehigion.

Presumably the dissenters and Karl Marx would have objected had opinm been the mass of the

83. Id. at 1605 .

84. See Sherbert v. Verner, 374 U.S. 398, 406-09 (1963).

85. The anarchy of the 1960 s was not caused by the free exercise of religion but by the Vietnam War. The Court conld have stopped that anarchy but declined to rule on the constitutionality of the war. E.g., Mora v. McNamara, 389 U.S. 934 (1967) (denying certiorari to 387 F.2d 862 (D.C. Cir. 1967), which dismissed a suit secking declaratory judgment on tle legality of the war). Apparently, some anarchies are preferable to others.

86. They actually have one of these parades annually in Transylvania. 
tunity for the races. ${ }^{87}$

The Court cited cases in which claimants asserted religious exemptions to soine of these laws. ${ }^{88}$

T: Did those courts grant the exemptions?

S: No. In every cited case the government prevailed. ${ }^{89}$

T: Then it's a toothless parade of horribles. ${ }^{90}$

S: The Court explained that the purpose of the parade was not to suggest that courts would grant the exemptions, but that courts would constantly be forced to inake these difficult decisions. ${ }^{91}$

T: This is the "anarchy" the Court was referring to?"2 Judges will have to decide hard cases?"

S: Apparently. The Court said that "it is horrible to contemplate that federal judges will regularly balance against the importance of general laws the significance of rehigious practice." $" 94$

T: But the essence of judging is having to judge, ${ }^{95}$ and courts have done it in this area for years. ${ }^{96}$ In fact, inany areas of constitutional law

87. Smith, $110 \mathrm{~S}$. Ct at $1605-06$ (citations omitted).

88. Id. (citing Susan \& Tony Alamo Found. v. Secretary of Labor, 471 U.S. 290 (1985) (minimum wage laws); Bob Jones Univ. v. United States, 461 U.S. 574, 603-04 (1983) (laws excluding corporations that racially discriminate from tax exemptions); United States v. Lee, 455 U.S. 252 (1982) (taxes); Gillette v. United States, 401 U.S. 437 (1971) (military service); Prince v. Massachusetts, 321 U.S. 158 (1944) (child labor laws); Cox v. New Hampslire, 312 U.S. 569 (1941) (traffic laws); Olsen v. Drug Enforcement Admin., 878 F.2d 1458 (D.C. Cir. 1989) (drug laws); Clutrch of the Lukumi Babula Aye, Inc. v. City of Hialeah, 723 F. Supp. 1467 (S.D. Fla. 1989) (animal cruelty laws); United States v. Little, 638 F. Supp. 337 (D. Mont. 1986) (environmental protection laws); Cude v. State, 237 Ark. 927, 377 S.W.2d 816 (1946) (compulsory vaccmation laws); Funkhouser v. State, 763 P.2d 695 (Okla. Crim. 1988) (manslaughter of a child by withholding medical treatment), cert. denied, 109 S. Ct. 2066 (1989).

89. See id. at 1606 n.5. Justice O'Connor wrote, "The Court's parade of horribles not only fails as a reason for discarding the compelling interest test, it instead demonstrates just the opposite: that courts have been quite capable of applying our free exercise jurisprudence to strike sensible balances between religious liberty and competing state interests." Id. at 1612-13 (O'Connor, J., concurring) (citation omitted).

90. Mixed metaphor alert! Ding ding ding ding. Cf., e.g., Sherbert v. Verner, 374 U.S. 398, 413 (1963) (Stewart, J., concurring) ("This case presents a double-barreled dilemma, which in all candor I think the Court's opinion has not succeeded in papering over."); G. BRANDRETH, supra note 67, at 227 (quoting Ian Fleming) ("Bond's knces, the Achilles' leel of all skiers, were beginning to ache."); W. SHAKESPEARE, HAMLET, act III, scene 1, 11. 56-60 ("To be, or not to be: that is the question/ Whether 'tis nobler in the mind to suffer/ The slings and arrows of outrageous fortune/ Or to take arms against a sea of troubles/ And by opposing end them?").

I rcalize that by criticizing Shakespcare, I am skating on hot water.

91. Smith, $110 \mathrm{~S}$. Ct. at 1606 n.5.

92. The Court would presumably refer to a taxi driver's rudeness as "civil strife."

93. And to think that some federal judges are only paid a paltry $\$ 130,000$ a year.

94. Smith, 110 S. Ct. at 1606 n.5 (emplrasis added). Well, it does sound like pretty grim work, compared to, for example, working in a coal mine.

95. Perhaps the Court thinks that judges should only be required to wear robes and sustain objections.

96. Of course, Smith's categorical approach will make free exercise cases easier for federal judges. The absence of alternatives clears the mind wonderfully. 
require courts to weigh the social importance of laws against their impact on constitutional rights. ${ }^{97}$ Why should balancing be forbidden only in the free exercise area?

S: The Court also argued that if "compelling interest" really means what it says, many laws will.not meet the test, ${ }^{98}$ and that "watering it down here would subvert its rigor in the other fields where it is applied," sucl as freedom of speech and equal protection. ${ }^{99}$

T: The Court has a point. The supervening governmental interests in the free exercise cases are not always truly compelling. For example, the governmental interests in compulsory military service, ${ }^{100}$ taxes, ${ }^{101}$ minimum wages, ${ }^{102}$ traffic laws, ${ }^{103}$ combating drng abuse, ${ }^{104}$ preventing animal cruelty, ${ }^{105}$ and environmental protection ${ }^{106}$ are important, but tliey would not justify racial classifications or infringements on the right of free speech. Although the Court has formally articulated the "compelling imterest" test in the free exercise area, it has in fact required something less: ${ }^{107}$ a governmental interest substantial enough to outweigh the free exercise claim. ${ }^{108}$

S: The Court hasn't consistently used the words "compelling interest" in the post-Sherbert free exercise cases, has it?

T: No, it hasn't. It has also articulated the test as: a governmental imterest "of the higliest order,"109 an interest "of such a high order," an "overriding governmental imterest," "11 and a "substantial governmen-

97. McConnell, supra note 76, at 1144 (citing, as examples, the commerce clause, the due process clause, and the free speech clause).

98. Smith, 110 S. Ct. at 1605.

99. Id.

100. See Gillette v. United States, 401 U.S. 437 (1971).

101. See United States v. Lee, 455 U.S. 252 (1982).

102. See Susan \& Tony Alamo Found. v. Secretary of Labor, 471 U.S. 290 (1985).

103. See Cox v. New Hampshire, 312 U.S. 569 (1941).

104. See Olsen v. Drug Enforcement Admin., 878 F.2d 1458 (D.C. Cir. 1989).

105. See Church of the Lukumi Babula Aye, Inc. v. City of Hialeah, 723 F. Supp. 1467 (S.D. Fla. 1989).

106. See United States v. Little, 638 F. Supp. 337 (D. Mont. 1986).

107. Kamenshine, Scrapping Strict Review in Free Exercise Cases, 4 CONST. CommENTARY 147, 154 (1987); Stone, Constitutionally Compelled Exemptions and the Free Exercise Clause, 27 WM. \& MARY L. REV. 985, 994 (1986).

108. '[T]alk of 'compelling,' 'paramount,' 'overriding' or 'essential' state interests is misleading. The standard is substantially different: is there a real, tangible (palpable, concrete, measurable), nonspeculative, non-trivial injury to a legitimate, substantial state intcrest?" Pepper, supra note 12, at 289 (footnote omitted).

109. McDaniel v. Paty, 435 U.S. 618, 628 (1978) (quoting Wisconsin v. Yoder, 406 U.S. 205, 215 (1972)).

110. United States v. Lee, 455 U.S. 252, 260 (1982).

111. Bob Jones Univ. v. United States, 461 U.S. 574, 603 (1983) (quoting Lee, 455 U.S. at 257. 58). 
tal interest." "112

S: The Smith Court also compared the constitutional scrutiny applied under the equal protection and free speech clauses. It argued that while the coinpelling interest test apphies to classifications based on race or the content of speech, that test does not apply to neutral laws that have the effect of disproportionately disadvantaging a particular racial group or interfering with speech. ${ }^{113}$

T: The compelling interest test is inapplicable to "effects" cases under the equal protection and free speech clauses. But that does not inean that those cases require no constitutional scrutiny at all. For exainple, in United States $v$. O'Brien, ${ }^{114}$ a protestor who burned his draft card $^{115}$ in front of a crowd was prosecuted under a law prohibiting the knowing destruction of draft cards. The Court held:

[W] hen "speech" and "nonspeech" elements are combined in the same course of conduct, a sufficiently important governmental interest in regulating the nonspeech element can justify incidental limitations on First Amendment freedoins. To characterize the quality of the governinental interest which nnust appear, the Court has employed a variety of descriptive terms: compelling; substantial; subordinating; paramount; cogent; strong. Whatever imprecision inheres in these terms, we think it clear that a government regulation is sufficiently justified if it is within the constitutional power of the Government; if it furthers an important or substantial governmental interest; if the governmental interest is unrelated to the suppression of free expression; and if the incidental restriction on alleged First Amendment freedorns is no greater than is essential to the furtherance of that interest. ${ }^{116}$

According to O'Brien, a neutral law that regulates conduct but has an incidental effect on first amendment freedoms inust be submitted to a balancing test, and the government's interest inust be a substantial or important one. Similarly, the Court has held that content-neutral time, place, and inanner restrictions inust be narrowly tailored to serve a substantial or significant governmental interest. ${ }^{117}$ As stated earhier, in the

112. Johnson v. Robison, 415 U.S. 361, 384 (1974) (quoting Gillette v. United States, 401 U.S. 437, $462(1971))$.

113. Smith, 110 S. Ct. at 1604 n.3 (citing Washington v. Davis, 426 U.S. 229 (1976) (police ennployment examination) and Citizen Publishing Co. v. United States, 394 U.S. 131, 139 (1969) (antitrust laws)).

114. 391 U.S. 367 (1968).

115. It is alleged that the U.S. governinent was not honest with the American people during the Vietnan War. It is safe to say that the government at least played games with language. For cxample, Colonel Opter, a U.S. Air Force press officer in Cambodia, told reporters after a bombing raid, "You always write it's bontbing, bombing, bombing. It's not bombing. It's air support." G. BRANDRETH, supra note 67 , at 220.

116. O'Brien, 391 U.S. at $\mathbf{3 7 6 - 7 7}$ (footnotes omitted).

117. E.g., City of Renton v. Playtime Theatres, 475 U.S. 41, 47 (1986); Clark v. Cominunity for Creative Non-Violence, 468 U.S. 288, 293 (1984); City Council v. Taxpayers for Vincent, 466 U.S. 
free exercise cases the Court has articulated the requisite governmental interest in various ways. In practice, however, the Court has essentially applied the $O^{\prime} B r i e n$ test. ${ }^{118}$

S: Even though both involve conduct, perhaps there is a difference between symbohic speech and the free exercise of religion.

$\mathrm{T}$ : Many, though not all, rehgious ceremonies and practices involve symbolic speech. Many practices are manifestations of faith and belief, designed to communicate to the participants, to others, and to God. For example, baptism, ${ }^{119}$ the sacrament of cominunion, ${ }^{120}$ wearing special clothing, ${ }^{121}$ dietary restrictions, ${ }^{122}$ placing a mezuzah by the door, ${ }^{123}$ and observance of the Sabbatl1 ${ }^{124}$ and other holy days, ${ }^{125}$ all have symbolic significance. ${ }^{126}$ By comparison, many areas of secular

789, 804-05 (1984); United States v. Grace, 461 U.S. 171, 177 (1983); Perry Educ. Ass'n v. Perry Local Educators' Ass'n, 460 U.S. 37, 45 (1983); Heffron v. International Soc'y for Krishna Consciousness, Inc., 452 U.S. 640, 648-49 (1981).

118. Kamenshine, supra note 107, at 152-54; see also Tushnet, The Constitution of Religion, 18 CoNN. L. REv. 701, 715 (1986) (Braunfield v. Braun, 366 U.S. 599 (1961), applied a test structurally the same as O'Brien).

119. E.g., Acts 22:16 (King James) ("[B]e baptized, and wash away thy sins, calling on the name of the Lord."); Romans 6:4 (King James) ("Therefore we are buried with him by baptism into death: that like as Christ was raised up from the dead by the glory of the Father, even so we also should walk in newness of life.").

120. E.g., Luke 22:19-20 (King James) (italics in original):

And he took bread, and gave thanks, and brake $i$, and gave unto thein, saying, "This is my body which is given for you; this do in remembrance of ine." Likewise also the cup after supper, saying, "This cup is the new testament in my blood, which is shed for you."

121. For example, in Judaisin the yarmulke (skullcap) einphasizes that a person is a servant of the Lord and shows reverence for God. H. DoNiN, To BE A JEW 180 (1972). The tzitzit (fringes) on the tallit (a four-cornered garment) serve as a reminder of all the commandments of the Lord. Id. at 155-59; Numbers 15:37-41. The tefillin (phylacteries) testify to the eternal covenant between God and Israel, symbolize Jewish faith and devotion, and serve as a reminder of all the commandments. H. DoNiN, supra, at 144-46; see Deuteronomy 6:8; $c f$. Tinker v. Des Moines Indep. Community School Dist., 393 U.S. 503, 505 (1969) (wearing black arm band was a mode of free expression).

122. The Torah associates Jewish dietary restrictions with a call to holiness. They are "an aspect of the broader requirements that Israel learn to distinguish between the unclean and the clean not only in food, but in all areas of life-the sexual, the moral, the ethical, the spiritual." H. DoNiN, supra note 121, at 154 . Dietary restrictions also remind people that they are to remain separate from the world. Seventh Day Adventists, Mormons, Hindus, and Muslims, among others, also follow dietary restrictions.

123. The mezuzah serves as a reminder of the Divine Presence and of the obligation to observe all the commandments. Id. at 145; Deuteronomy 6:6-9.

124. Ezekiel 20:20 (King James) ("And hallow my sabbaths; and they shall be a sign between me and you, that ye may know that I am the LORD your God.") (capitalization in original). In Judaism, the Sabbath is a memorial to the creation of the world and to the exodus from Egypt. $H$. DoniN, supra note 121, at 65-70; see also Exodus 20:11; Deuteronomy 5:15. Preventing someone from observing the Sabbath also prevents her from participating in worship services and rituals held on the Sabbath, and in that way inhibits her free speech rights.

125. See H. DoNiN, supra note 121 , at $209-70$, for a discussion of the significance of holy days in Judaism.

126. [T] he notion of freedom of religious belief carries with it the correlative idea of freedom of expression in ceremonial forms. Although the Court [in Reynolds v. United 
law, including wills, contracts, and oaths of office, recognize the communicative value of cereniony in inipressing upon the participants the importance of particular ideas and actions. Why shouldn't rehgious practices that are performed for rehgiously symbohic and communicative reasons ${ }^{127}$ enjoy at least the same level of constitutional protection as other expressive conduct, such as burning one's draft card? ${ }^{128}$

S: Those rehgious practices might be protected under the free speech clause. With respect to noncommunicative religious conduct, however, $S$ mith held that the free exercise clause requires no balancing of interests at all. ${ }^{129}$

T: According to $S$ mith, a shight or even trivial government interest that has the effect of altering or even crushing ${ }^{130}$ a rehgion raises no issue under the free exercise clause. For example, a governmental ban on wine could include the sacramental use of wine. ${ }^{131} \mathrm{~A}$ ban on serving alcohol to mimors could prohibit giving wine to children at communion or at a

\footnotetext{
States, 98 U.S. 145 (1878)] did not advert to this point, it seems unlikely that it would have permitted interference with symbohic religious rituals unless they infringed significantly upon the public health, welfare, or morals. If not, the free speech guarantee of the first amendment would assure proteetion for such forms of expression.

Giannella, supra note 75 , at 1387.

127. Of course, not all rehgious practices are engaged in for communicative purposes. To assume that only commumicative rehigious practices are proteeted could render the free exercise clause redundant in hight of the freedoms of speech and assembly. Clark, supra note 27, at 336; Choper, Defining "Religion" in the First Amendment, 1982 U. ILL. L. REV. 579, 581-84. The position that the boundaries of the free exercise clause should be defined by those of the free speech clause has been criticized as "the reduction principle." See Ingber, Religion or Ideology: A Needed Clarification of the Religion Clauses, 41 STAN. L. REV. 233, 241 (1989); Tushnet, supra note 118, at
} 713.

128. Or, for that matter, burning the flag of the United States? See, e.g., United States v. Eichman, 110 S. Ct. 2404 (1990) (flag burning as a node of expression enjoys full proteetion of the first amendnient); Texas v. Johnson, 109 S. Ct. 2533 (1989) (defendant's act of burning flag during protest rally was expressive conduct protected by the first amendment). The flag deeisions did not enjoy enthusiastic popular support. After the decisions, Congress had to contemplate enacting a law banning the burning of Suprene Court Justices' robes.

On the nightly news, we often see people in the Middle East burning American flags. Who do those people think they are-Americans? Also, I can't figure out where they get all those flags. Do the governments of those countries have a lucrative American flag-making business on the side?

129. See also Sherbert v. Verner, 374 U.S. 398, 406 (1963) (quoting Thomas v. Collins, 323 U.S. 516,530 (1945)) ("It is basic that no showing merely of a rational relationship to some colorable state interest would suffice [to justify an infringenient of religious liberty]; in this highly sensitive constitutional area, '[o]nly the gravest abuses, endangering paramount interests, give occasion for permissible limitation." ").

130. For example, in Wisconsin v. Yoder, 406 U.S. 205 (1972), the Court accepted expert testiniony that compulsory public school attendance threatened the Amish religion with extinction. Id. at 212, 218-19.

131. The analogy to the sacramental use of peyote in Smith is as unavoidable as it is indistinguishable. See Smith, 110 S. Ct. at 1618 n.6 (Blackmun, J., dissenting). During Prohibition, the federal government exempted such use of wine. National Prohibition Act, ch. 85, tit. II, § 3, 41 Stat. 305, 308-09 (1919), repealed by Liquor Law Repeal and Enforcenient Act, ch. 740, tit. I, § 1, 49 Stat. 872, 872 (1935). However, it is doubtful that each of the many dry counties in the United States provides the same exception. 
Passover Seder. ${ }^{132}$ A law regulating the slaughter of animals could eliminate kosher slaughter. ${ }^{133}$ Laws could compel school attendance on the Sabbath or subject rehigious leaders to nuandatory retirement. Antidiscrimination laws could deprive churches of the right to prefer their own meinbers as teachers in their private schools, force churches to disregard gender, marital status, and sexual preference in ordaining priests or rabbis, ${ }^{134}$ forbid sexual segregation in Orthodox Jewish synagogues, ${ }^{135}$ and prohibit separate dormitories for inen and women at religious colleges. By barring persons with criminal convictions from serving as officers of organizations, ${ }^{136}$ a state could eliminate ministers who have been convicted of trespass or other civil disobedience in protesting on such issues as civil rights, ${ }^{137}$ treatment of the poor, ${ }^{138}$ the arms race, ${ }^{139}$ or war. By forcing changes in the composition, structure, and practices of religious groups, the government can change the rehigious groups themselves. ${ }^{140}$

S: Many people would find some of those results desirable.

T: That is precisely the danger. Majorities can be tempted to force minority religions to adopt changes that violate the minority's religious doctrines and beliefs, ${ }^{141}$ and thus seriously infringe on religious liberty in our pluralistic society. ${ }^{142}$ They can protect their own rehigious prefer-

132. See Rabinove, Court Treads Heavily on Religious Freedom, Deseret News, July 16-17, 1990 , at $6 \mathrm{~A}$.

133. Id.

134. Before Smith, courts held that title VII did not apply to the church-minister relationship because such an application would violate the free exercise clause. See McConnell, supra note 76, at 1142 n.141; see also, e.g., Rayburn v. General Conference of Seventh Day Adventists, 772 F.2d 1164, 1171-72 (4th Cir. 1985), cert. denied, 478 U.S. 1020 (1986); EEOC v. Southwestern Baptist Theological Seminary, 651 F.2d 277, 285 (5th Cir. 1981) (dictum), cert. denied, 456 U.S. 905 (1982); McClure v. Salvation Army, 460 F.2d 553, 561 (5th Cir.), cert. denied, 409 U.S. 896 (1972).

135. McConnell, supra note 76, at 1143 .

136. After all, criminals should not be permitted to serve in positions of leadership and trust-at least not in positions below the Cabinet level.

137. Much of the force behind the civil rights and abolition movements came from churches, and many of the leaders in those movements were ministers. For a discussion of theological aspects of Dr. Martin Luther King, Jr.'s civil rights vision, see Cook, Beyond Critical Legal Studies: The Reconstructive Theology of Dr. Martin Luther King, Jr., 103 HARV. L. REv. 985, 1018-41 (1990).

138. Cf. National Conference of Catholic Bishops, Economic Justice for All: Pastoral Letter on Catholic Social Teaching and the U.S. Economy (Nov. 18, 1986).

139. Cf. National Conference of Cathohic Bishops, The Challenge of Peace: God's Promise and Our Response (May 3, 1983).

140. Cf. Gedicks, Toward a Constitutional Jurisprudence of Religious Group Rights, 1989 Wis. L. REV. 99, 110-12 (regulation of religious group membership will destroy group's character).

141. Religious minorities need protection from others. After all, "Friends may come and go, but enemies accumulate." Thomas Jones, in R. BYRNE, supra note 1, at No. 563.

142. There is room in America for many religions. However, some people try to run over others' dogma with their karma. 
ences ${ }^{143}$ while crushing those that they do not share. ${ }^{144}$ Smith means that a legislative majority at any level of government-national, state, county, or city - can inpose whatever changes on minority religions, ${ }^{145}$ or on any rehigion, that it desires. ${ }^{146}$

S: But your test does not change that result. Almost all criminal laws are supported by a substantial or important governmental interest.

$T$ : It is not the government's broad interest im enforcing a particular law that is weighed against a free exercise claim, but rather the government's narrow interest in refusing to make a free exercise exemption. ${ }^{147}$ For example, the government has a substantial interest in compulsory education. Nonetheless, Yoder held,

Where fundamental claims of religious freedom are at stake, [the Court] cannot accept such a sweeping claim [that a State's interest in compulsory education is compelling]; despite its admitted validity in the generality of cases, we must searchingly examine the interests that the State seeks to promote ... and the mipediment to those objectives that would flow from recognizing the clanned Amish exemption. ${ }^{148}$

Therefore, the O'Brien test is workable. But the Court refused to consider any intermediate levels of constitutional scrutiny. It concluded that since compelling interest scrutiny is too strict, no scrutiny at all should apply. ${ }^{149}$

S: The Court did not leave free exercise rights unprotected. It noted, "Values that are protected against government interference through enshrinement in the Bill of Rights are not thereby bamished from the political process." 150 Democratic legislatures can grant protection to free exercise rights.

143. The proponents of exemption ... observe that powerful and influential religions will usually receive adequate protection in the political arena. One rarely sees laws that force mainstream Protestants to violate their consciences. Judicially enforceable exemptions under the free exercise clause are therefore needed to ensure that unpopular or unfamiliar faiths will receive the same consideration afforded mainstream or generally respected religions by the representative branches.

McConnell, supra note 7, at 1419-20 (footnote omitted).

144. Both the exemption and no-exemption views can be expressed in terms of "neutrality" toward religion, but the way in which the two views define "neutrality" differs. Under the no-exemption position, a law or government practice is "neutral" if it makes no reference to religion and has a secular justification unrelated to the suppression of retigion. Under the exemption position, a law or governmental practice is not "neutral" if it embodies the majority's view on a contested question of religious significance to the minority, even if that question is of no religious significance to the majority.

Id. at 1419 (footnotes omitted).

145. Culture is always linked to power. Max Weinreich observed, "A language is a dialect with an army and navy." R. BYRNE, supra note 1, at No. 608.

146. Then again, 100,000 lemmings can't be wrong. Id. at No. 558 .

147. Smith, 110 S. Ct. at 1617 (Blackmun, J., dissenting).

148. Wisconsin v. Yoder, 406 U.S. 205, 221 (1972) (citations omitted).

149. Since the prescription on its eyeglasses was too strong, the Court preferred to be sightless.

150. Smith, $110 \mathrm{~S}$. Ct. at 1606. 
T: Small comfort. ${ }^{151}$ "Discrete and msular minorities"152 often cannot protect themselves adequately in the legislative process. The right to practice one's religion should not be reduced to a question of political influence, completely subject to the whims of transient $t^{153}$ and shiftimg ${ }^{154}$ majorities. ${ }^{155}$ Justice Jackson wrote:

The very purpose of a Bill of Rights was to withdraw certain subjects from the vicissitudes of political controversy, to place them beyond the reach of majorities and officials and to establish them as legal principles to be applied by the courts. One's right to life, liberty, and property, to free speech, a free press, freedom of worship and assembly, and other fundamental rights may not be submitted to vote; they depend on the outcome of no elections. ${ }^{156}$

Assuming that citizens should render unto Caesar the things that are Caesar's, ${ }^{157}$ under Smith the sole judge of whether Caesar is asking too much is Caesar himself. ${ }^{158}$ "[T] $]$ he government's perception of public need defines the boundaries of freedom of conscience."159 Under this approach, "one renders unto Caesar whatever Caesar demands and unto God whatever Caesar permits."160

\section{S: The Court reasoned,}

151. It's like warming the water before drowning the cat.

152. United States v. Carolene Prods. Co., 304 U.S. 144, 153 n.4 (1938).

153. Israel Zangwill observed, "Every dogma has its day." G. LIEBERMAN, supra note 2, at 202.

154. Every majority religion is a past (and possibly future) minority. When times change, the sacred cows come home to roost with a vengeance. (Mixed metaphor alertl) G. BRANDRETH, supra note 67 , at 227 .

In one Eastern European country, the Communist Party decided on a new approach for recruiting new members. It said, "If you bring in one new member, you don't have to pay dues. If you bring in two new members, you don't have to belong to the party yourself. And if you bring in three new members, we'll give you a certificate saying that you never were a member of the party."

155. "[T] $]$ he First Amendment was enacted precisely to protect the rights of those whose religious practices are not shared by the majority and may be viewed with hostility. The history of our free exercise doctrine amply demonstrates the harsh impact majoritarian rule has had on unpopular or emerging religious groups ...." Smith, 110 S. Ct. at 1613 (O'Connor, J., concurring).

156. West Virginia State Bd. of Educ. v. Barnette, 319 U.S. 624, 638 (1943).

157. Matthew 22:21.

158. Our Nation has preserved freedom of religion, not through trusting to the good faith of individual agencies of government alone, but through the constitutionally mandated vigilant oversight and checking authority of the judiciary.

... [I]n pluralistic societies such as ours, institutions dominated by a majority are mevitably, if inadvertently, insensitive to the needs and values of minorities when these needs and values differ from those of the majority. ... A critical function of the Religion Clauses of the First Amendment is to protect the rights of members of minority religions against quiet erosion by majoritarian social institutions that dismiss minority beliefs and practices as unimportant, because unfamiliar. It is the constitutional role of this Court to ensure that this purpose of the First Amendment be realized.

Goldman v. Weinberger, 475 U.S. 503, 523-24 (1986) (Brennan, J., dissenting).

159. McConnell, supra note 7 , at 1434 .

160. W. Berns, The First AMENDMENT ANd the Future of AMERICAN Democracy 44 (1976). 
Just as a society that behieves in the negative protection accorded to the press by the First Amendment is likely to enact laws that affirmatively foster the dissemination of the printed word, so also a society that beheves in the negative protection accorded to rehious behef can be expected to be sohcitous of that value in its legislation as well. ${ }^{161}$

T: This logic would equally justify abolishing the constitutional protection of freedom of the press, and, for that matter, every constitutional right. It rests on the premise that a society that adopted tlie Bill of Rights would not seek to violate tliose rights. Unfortunately, history ${ }^{162}$ proves the premise false. ${ }^{163}$

Moreover, Smith changes the nature of the legislative debate. When legislatures grant requests for religious accommodation, they sometimies do so because they perceive that those requests are legitimately grounded in the free exercise clause. After Smith, legislators can reply that conduct is beyond the scope of the free exercise clause and therefore the claimants have no cognizable argument grounded in constitutional values. By holding that the Constitution protects behefs but not conduct, the Court shapes attitudes concerning whicli aspects of rehgious behavior deserve accommodation $\mathrm{m}$ our society, ${ }^{164}$ and this in turn can affect the level of voluntary legislative accommodation. ${ }^{165}$ Moreover, legislatures are sometimies motivated to create rehigious exemptions because they want their legislation to survive constitutional attack. Smith's elimination of that motivation could result im fewer exemptions.

Lastly, some people argue that granting exemptions can constitute

161. Smith, 110 S. Ct. at 1606.

162. At the constitutional convention, John Dickinson of Delaware said, "Experience must be our only guide. Reason may mislead us." C. Bowen, Miracle at Philadelphia 44 (1966).

163. No chapter in human history has been so largely written in terms of persecution and intolerance as the one dealing with rehigious freedom. From ancient times to the present day, the ingenuity of inan has known no limits in its ability to forge weapons of oppression for use against those who dare to express or practice unorthodox rehgious beliefs.

Prince v. Massachusetts, 321 U.S. 158, 175-76 (1944) (Murphy, J., dissenting).

164. [L]aw has the capacity to affect ways of thinking and our culture through its educative and symbolic influence. When a court, especially the Supreine Court, pronounces in the name of the Constitution upon the meaning of racial justice, sexual morality, or any other subject, a cultural lesson is taught. Most people revere the Constitution as a basic compact that defines American civic morality. A decision does more than decide a case; it adds weight to one side of our cultural war, even when the decision is in fact not supported by the actual Constitution.

R. BORK, THE TEMPTING OF AMERICA 137-38 (1990); see also Tribe, supra note 24.

165. Dallin H. Oaks has written: "[M] any understand the law today as being hostile rather than neutral toward rehigion. ... In the past, rehion had been an accepted part of public life in America. It has become something that had to prove its right to remain in the public square." Oaks, Government Should Not Censor Prayers, The Universe, May 30, 1990, at 4. Others have also written that current liberal theory is antagonistic to religion. See, e.g., Carter, Evolutionism, Creationism, and Treating Religion as a Hobby, 1987 DukE L.J. 977, 985-92; Gedicks \& Hendrix, Democracy, Autonomy, and Values: Some Thoughts on Religion and Law in Modern America, $60 \mathrm{~S}$. CAL. L. REv. 1579, 1604-05 (1987). 
an establishment of religion. ${ }^{166}$ However, the free exercise clause has been viewed as requiring some accommodation of religious conduct. ${ }^{167}$ Since under Smith the free exercise clause no longer requires any accommodation, the argument that the establishment clause prohibits religious exemptions could prevail. ${ }^{168}$ In other words, the Court may have altered the debate by destroying the equilibrium.

\section{S: The Court admitted that}

leaving accommodation to the political process will place at a relative disadvantage those religious practices that are not widely engaged in; but that unavoidable consequence of democratic government must be preferred to a system in which each conscience is a law unto itself ${ }^{169}$ or in which judges weigh the social importance of all laws against the centrality of all rehigious beliefs. ${ }^{170}$

T: The Court professes that it would like to protect religious minorities, ${ }^{171}$ but that it can't because of the "law unto itself" argument and because these issues are too difficult or burdensome for federal judges to decide. As we liave seen, though, the "law unto itself" argument is a red lerring. ${ }^{172}$ What remains is that, in the Court's view, the protection of minority rehigious practices ${ }^{173}$ simply is not wortl the trouble it imposes on federal courts, and this conclusion justifies reheving those courts of their constitutional responsibility ${ }^{174}$ to protect the rights of reh-

166. See, e.g., United States v. Lee, 455 U.S. 252, 263 n.2 (1982) (Stevens J., concurring) (exemption to social security tax would violate establishment clause); Stone, supra note 107, at 987; cf. Note, Religious Exemptions Under the Free Exercise Clause: A Model of Competing Authorities, 90 YALE L.J. 350, 356 (1980).

167. For discussion of the tension between the free exercise and establishment clauses, see Choper, The Religion Clauses of the First Amendment: Reconciling the Conflict, 41 U. PITT. L. REV. 673 (1980); Giannella, supra note 75, at 1388-89; McConnell, supra note 21, at 1 (tension arises from incorrect characterization of first amendment as promoting separation of church and state instead of religious liberty).

168. Wrongly, in my judgment. "Such exemptious plainly do not reflect legislative approval of the specific beliefs or practices accoininodated by the law; their very status as exemptions to more general, and contrary, policies sliows that they are the product of tolerance, not approval." Sinith, The Restoration of Tolerance, 78 CALIF. L. REV. 305, 354 (1990).

169. It is odd that if one person believes in an extra-rational reason for disobeying a law, he can be acquitted for insanity. However, if many people believe in the same reason, they have no defense. Cf. Garvey, Free Exercise and the Values of Religious Liberty, 18 CONN. L. REV. 779, 798-801 (1986). Some forms of insanity are not so bad. For example, sehizophrenia beats dining alone. $R$. BYRNE, supra note 1 , at No. 326.

170. Smith, $110 \mathrm{~S}$. Ct. at 1606.

171. Cross its heart and liope to die.

172. Or a pile of garbage. Or a sinoke screcn. Or blue sinoke and mirrors. Or a red lierring on a pile of garbage behind a smoke screen of blue sinoke and mirrors. See supra note 90.

173. When I was growing up, I was unaware of religious persecution in tlie world. My parents were overprotective, and I led a very sheltered childhood. For example, iny tricycle had seven wheels. My parents would not let me swing. They sat me on a swing, ran back and forth, and said, "It looks similar to this."

174. Of course, they could always assign the responsibility to private enterprise. For example, President Reagan's draft budget for 1987 contained a proposal to sell the FHA to private bidders. In 
gious minorities. ${ }^{175}$ Consequently, according to Smith, except in unemployment compensation the free exercise clause has no meaning.

S: Not true. The Court said that it prohibits governmental regulation of behefs. ${ }^{176}$ For example, "[t]he government may not compel affirmation of rehigious belief, punish the expression of religious doctrines it believes to be false, impose special disabilities on the basis of rehigious views or religious status, or lend its power to one or the other side in controversies over religious authority or dogma."177

$T$ : Compelling the affirmation of rehigious belief and punishing the expression of religious doctrines violate the freedom of speech. ${ }^{178}$ In addition, the Court's examples violate the estabhishment clause. ${ }^{179}$ Under Lemon v. Kurtzman, ${ }^{180}$ a law creates an unconstitutional estabhishment of rehigion if it fails to meet a three-pronged test: "First, the statute must have a secular legislative purpose; second, its principal or primary effect must be one that neither advances nor inhibits rehgion; finally, the statute must not foster 'an excessive government entanglement witl rehion.' "181 Compelling the affirmation of rehgious behef, pumishing the expression of rehgious doctrines the government beheves to be false, and imposing special disabilities on the basis of rehgious views or religious status presumably violate the first and second prongs of the test. Lending governmental power to one or the otlier side in controversies over rehigious authority or dogma violates the third prong, ${ }^{182}$ and soinetimes the otlier two prongs as well. Does the free exercise clause prohibit anything else?

response, ACLU Executive Director Ira Glasser sent a letter to Attorney General Edwin Meese III offering to buy the Justice Department. The ACLU said that it would settle for the Civil Rights Division alone if the entire department weren't up for grabs. Mr. Glasser wrote that he believed that his organization "can make an attractive offer which will satisfy your interest in divesting the government of unwanted responsibilities." In addition, he wrote that the ACLU could "restore a healthy balance sheet to your Civil Rights Division, whose liabilities now exceed its assets to a degree that has long-term investors in justice very worried." Letter from Ira Glasser to Edwin Meese III (Dec. 18, 1985) (report of letter on file with the author).

175. This means that the free exercise rights of minorities will not be protected in the future. The future is much like the preseut, only longer. Don Quisenberry, in R. BYRNE, supra note 1, at No. 514.

176. Smith, $110 \mathrm{~S}$. Ct. at 1599.

177. Id. (citations omitted).

178. Cf. West Virginia State Bd. of Educ. v. Barnette, 319 U.S. 624, 642 (1943) (government cannot compel flag salute).

179. See, e.g., Larsou v. Valente, 456 U.S. 228, 244-46, 255 (1982) (law demonstrating preference for some rehigions over others); McDamiel v. Paty, 435 U.S. 618, 636-42 (1978) (Brennan, J., concurring) (law banning clergy from serving as state legislators); Presbyterian Church v. Hull Church, 393 U.S. 440,449 (1969) (judicial settling of religious disputes); Torcaso v. Watkins, 367 U.S. 488, $492-95$ (1961) (law compelling affirmation of religious behief).

180. 403 U.S. 602 (1971).

181. Id. at 612-13 (quoting Walz v. Tax Comm'n, 397 U.S. 664, 674 (1970)).

182. See Serbian E. Orthodox Diocese v. Milivojevich, 426 U.S. 696, 709 (1976) (resolving property dispute by examining church law entangles government in rehion). 
S: Yes. The Court said:

[W] think ${ }^{183}$ (though no case of ours has involved the point), ${ }^{184}$ that a state would be "prohibiting the free exercise [of rehgion]" if it sought to ban such acts or abstentions ouly when they are engaged in for rehigious reasons, or ouly because of the rehigious behef that they display. It would doubtless be unconstitutional, for example, to ban the casting of "statues that are to be used for worship purposes," or to prohibit bowing down before a golden calf. ${ }^{185}$

T: These examples also violate the first two prongs of the Lemon test: they have no legitimate secular purpose and have the principal effect of inhibiting religion. Consequently, according to the Court's logic, everything prohibited by the free exercise clause is already prohibited by the estabhishinent clause, and the free exercise clause is superfluous. Yet the Court has held that "despite a general harmony of purpose between the two rehigious clauses of the First Amendment, the Free Exercise Clause no doubt has a reach of its own."186

S: I gather that you don't consider Smith an admirable decision?

T: What is there to admire ${ }^{187}$ The Court wanted to reacli its result in the worst way, and it succeeded. It referred to no historical evidence whatsoever, instead basing the decision entirely on its own notions of policy. The Court distinguished one line of free exercise cases as restimg on other grounds, when in fact those cases explicitly rested on the free exercise clause. It distinguished another line of cases as relating to unemployment compensation systems that examine individual reasons for apphicants' conduct, when in fact Smith itself was such a case and the whole distimction was, im any event, contrived. The Court distinguished other cases by assertimg that it liad only "purported" to apply the coinpelling interest test in those cases. The Court asserted that it had declined to apply the compelling mterest test in recent cases, citing military, prison, and internal affairs cases, but disregarding a tax case that applied tlie compelling interest test only the previous Term. After sweeping away the precedents in this maimer, the Court presented two affirmative arguinents supporting its holding. The main argument was that permittimg free exercise exemptions would permit every person to becoine a law unto himself. Under free exercise jurisprudence, however, it is the judiciary and not the individual that decides what the reach of the law will be. The Court said that any society adopting such a system

183. Therefore, we are.

184. Not surprisingly, given the unrealistic nature of the hypotheticals.

185. Smith, $110 \mathrm{~S}$. Ct. at 1599.

186. Gillette v. United States, 401 U.S. 437, 461 (1971).

187. Professor Steven D. Smith has written that "calling the arguments in Smith 'implausible' is inuch like describing winters in northern Alaska as "cool." " Letter froin Steven D. Sinith to Jaines D. Gordon III (Aug. 24, 1990) (on file with author). 
would be courting anarchy, blinking aside the fact that this had been the systein in the United States for years. The Court presented a list of cases as a parade of horribles, but then had to admit that, in all those cases, the government's interest had prevailed.

This admission led the Court to its second argunent: it was "horrible" that courts would have to make decisions involving the free exercise clause. This argument imphes that it is either too burdensome or mipossible to make principled decisions $m$ this area. But it is the business of federal courts to make difficult constitutional decisions, ${ }^{188}$ and it is their duty to protect the constitutional rights of minorities. Since the Court felt that strict scrutiny was too strict, it concluded that no constitutional scrutiny at all (except rational basis) should apply, ignoring the intermediate scrutiny that apphies in analogous free speech cases and that has in fact been applied in the free exercise cases theinselves.

The Court held that free exercise protection would have to come from the legislatures. It reasoned that legislatures are likely to be as solicitous of religious practices as they are of freedon of the press, an argninent that would equally justify abolishing the constitutional right of freedoin of the press. The Court adimitted that leaving the issue to legislatures disadvantages minority religions, but asserted that this unfairness is preferable to a system in which each conscience is a law unto itself or in which courts have to decide these issues.

Smith essentially rendered the free exercise clause a dead letter, because (except in uneinployment compensation) everything prohibited by the free exercise clause is already prohibited by the establishinent clause. In Cantwell v. Connecticut, ${ }^{189}$ the Court lield that the free exercise clause is such a part of the "fundaniental concept of hiberty" that it applies to the states througli the fourteenth amendnient. ${ }^{190}$ In Smith, the Court held that, except in uneniployment coinpensation, this fundainental right has no independent significance and protects nothing at all. In essence, Smith "depublished" the free exercise clause.

During the congressional discussion of the first amendinent, Representative Daniel Carroll of Maryland observed that "the rights of conscience are, in their nature, of peculiar dehicacy, and will little bear the gentlest touch of governmental hand." ${ }^{191}$ For that reason, the fram-

188. Nearly all hard constitutional decisions require a balancing of interests in some sense; even where the case turns on the meaning of bright-line principles the Court must engage in a process of evaluating and comparing the interests involved, a process justified ultimately only by the constitutional role given the Court by Marbury v. Madison.

Clark, supra note 27, at 330.

189. 310 U.S. 296 (1940).

190. Id. at 303 .

191. I ANNALS OF CONG. 757 (J. Gales ed. 1789), quoted in Braunfield v. Braun, 366 U.S. 599, 616 (1961) (Brennan J., concurring in part and dissenting in part). 
ers included the first amendment in the Bill of Rights and did not simply leave the issue to the legislature's good faith. As Chief Justice Marshall wrote in Marbury v. Madison: ${ }^{192}$

The powers of the legislature are defined, and limited; and that those limits may not be mistaken, or forgotten, the constitution is written. To what purpose are powers limited, and to what purpose is that limitation committed to writing, if these limits may, at any time, be passed by those intended to be restrained? ${ }^{193}$

By transparently mampulating both precedent and logic, the Court succeeded in abdicating its constitutional duty to enforce the free exercise clause.

In any event, although Smith excised the free exercise clause from the Bill of Rights for people in the lowlands, here on the mountaintop I can practice my religion in peace.

S: Who is that coming up the mountain?

192. 5 U.S. (1 Cranch) 137 (1803).

193. Id. at 176. 